\title{
IMPLEMENTASI PENDIDIKAN ISLAM ANAK DARI ORANG TUA LULUSAN PONDOK PESANTREN
}

\author{
Navisatul Munawwaroh'1), Ashif Az Zafi') \\ 1,2 Institut Agama Islam Negeri (IAIN) Kudus \\ 1navisahmunawwaroh25@gmail.com \\ 2ashifazzafi@iainkudus.ac.id
}

\begin{abstract}
ABSTRAK
Permasalahan yang ada sekarang ini adalah banyak anak kurang mengerti secara mendalam agama Islam, faktor utama dari hal tersebut dikarenakan orang tua yang kurang memerhatikan pendidikan Islam anak. Pengaruh pendidikan orang tua juga menjadi kaitan utama dalam pendidikan anak, karena orang tua yang berada dalam waktu yang banyak dengan anak dari anak kecil. Peran orang tua sangat berarti bagi pendidikan anak. Orang tua yang paham pendidikan Islam lebih dalam misalnya pendidikan terakhir mereka pondok pesantren, maka hal tersebut menentukan cara dan penyampaian pendidikan Islam yang tepat diterapkan kepada anak. Penelitian ini bertujuan untuk mengetahui implementasi pendidikan Islam dari orang tua pondok pesantren, apakah anak akan memiliki agama dan moral yang baik atau tidak berdasarkan orang tua pondok pesantren. Penelitian ini merupakan penelitian deskriptif dengan pendekatan kualitatif. Metode pengambilan data menggunakan observasi dan wawancara. Hasil penelitian ini orang tua pondok pesantren dapat menerapkan dalam kehidupannya di keluarga dengan baik, terutama dalam mengajarakan pendidikan Islam pada anak.
\end{abstract}

Kata Kunci: Implementasi, pendidikan Islam, anak, orang tua, pondok pesantren.

\begin{abstract}
The problem now is that many children lack a deep understanding of the religion of Islam, the main factor of this is because parents do not pay much attention to children's Islamic education. The influence of parental education is also a major link in children's education because parents who are in a lot of time with children of small children. The role of parents is very meaningful for children's education. Parents who understand Islamic education more deeply, for example, their last education of Islamic boarding school, then determine the way and delivery of Islamic education that is appropriate for
\end{abstract}


children. This study aims to determine the implementation of Islamic education from parents of boarding schools, whether children will have good religion and morals or not based on parents of boarding schools. This research is a descriptive study with a qualitative approach. The data collection method uses observation and interviews. The results of these study parents of Islamic boarding schools can apply in their lives in the family well, especially in teaching Islamic education to children.

Keywords: Implementation, Islamic education, children, parents, Islamic boarding school.

\section{PENDAHULUAN}

Islam meletakkan beban yang berat di atas pundak pendidikan Islam yaitu mengenai pengajaran-pengajaran tentang agama Islam, adapun kemajuan yang ingin dicapai adalah kebahagiaan dunia dan akhirat (Remiswal dan Firman, 2018). Pendidikan Islam juga dapat dilaksanakan melalui seorang santri di pondok pesantren. Setelah dari pondok pesantren, seorang santri tersebut disebut sebagai alumni pondok pesantren (pondok pesantren). Kualitas alumni pondok pesantren diharapkan pada tujuan utama pesantren yang hendak menyiapkan alumni-alumninya yang tafaqquh fi al-din (memiliki pemahaman yang baik) yang mencerminkan kualitas muslim yang ahli dalam bidang agama (Muhdi, 2018).

Alumni pondok pesantren diharapkan melaksanakan pengajaran agama Islam yang telah dipelajarinya dikehidupan mereka. Saat sebelum menikah ataupun setelah mereka menikah dan memiliki anak sekalipun. Hendaknya anak diajari pengajaran agama Islam yang telah dipelajarinya dari pondok pesantren tersebut. Fakta kondisi kehidupan yang ada sekarang ini anak lebih suka mendengarkan musik-musik pop daripada mendengar nyanyian-nyanyian pujian kepada Tuhan. Hal tersebut karena kurangnya penanaman pendidikan agama Islam dari para orang tua anak. Karena pada dasarnya pendidikan Islam dari orang tua merupakan orang pertama yang dapat melaksanakan pendidikan agam Islam kepada anak. Orang tua dapat mengendalikan tingkah laku anak sesuai dengan pelajaran hidup yang telah dilaluinya.

Pengajaran orang tua kepada anak dapat dilakukan melalui tingkah laku yang baik, tidak hanya memberikan nasehat akan tetapi melaksanakan hal-hal yang baik agar anak meniru apa yang telah dilakukan orang tua. Karena pada dasarnya sifat anak adalah meniru dari orang sekitarnya, Sehingga ketika orang-orang di sekitarnya memiliki sikap dan sifat yang baik dalam keseharian mereka di depan anak, maka anak akan meniru sikap dan sifat yang baik pula untuk kehidupan sehari-harinya 
(Bukhari, 2015). Hal tersebut tetaplah disebut sebagai pendidikan Islam, meskipun dilaksanakan di rumah sekalipun. Karena lingkungan anak yang paling awal adalah lingkungan keluarga. Lingkungan dimana anak dan orang tua bersama.

Penelitian ini dimaksudkan untuk mengetahui penerapan pendidikan Islam dari orang tua pondok pesantren kepada anaknya. Apakah anak tersebut diajari dengan baik sesuai dengan ajaran agama Islam yang telah dipelajarinya atau tidak, dan apabila anak yang telah diajari orang tuanya dengan pendidikan Islam yang baik apakah anak tersebut akan menerapkan pengajaran yang telah diajarakan oleh orang tuanya tersebut dengan baik atau tidak. Penerapan pendidikan Islam dari orang tua sebagai pendidik pertama anak, meliputi keimanan dan kelslaman atau yang umat Islam kenal sebagai rukun iman yaitu percaya bahwa Allah itu ada sebagai tuhannya, percaya bahwa malaikat Allah itu ada, percaya dengan isi kitab Alquran, percaya bahwa ada Rasul Allah yang menyampaikan kitab-kitab Allah, percaya datangnya hari kiamat suatu hari nanti, dan percaya bahwa ada qadha (ketetapan yang tidak dapat diubah) dan qadar (ketetapan yang dapat diubah) Allah dan rukun Islam yaitu membaca syahadat, melaksanakan sholat, melaksanakan puasa, melaksanakan zakat, dan melaksanakan haji (Ayuhan, 2012).

Mengetahui penerapan pendidikan Islam dari orang tua pondok pesantren membuat kita tahu apakah pendidikan Islam dari orang tua pondok pesantren menjamin pendidikan agama Islam yang lebih baik untuk anak mengenai akidah, syariah dan akhlak anak tersebut. Penelitian ini akan dijabarkan secara lebih spesifik (khusus) mengenai implemenstasi pendidikan Islam dari orang tua pondok pesantren. Hal ini dimaksudkan mengenai cara mendidik untuk anak-anak yang orang tuanya lulusan pondok pesantren. Baik cara mendidik di dalam rumah maupun untuk pendidikan anak selain di dalam rumah yaitu di sekolah atau lingkungan sekitar tempat tinggal. Dalam penelitian ini nantinya akan diketahui secara jelas tentang implemesntasi pendidikan Islam dari orang tua pondok pesantren.

\section{METODE PENELITIAN}

Pengambilan data pada penelitian ini menggunakan metode observasi dan wawancara. Pengambilan data dengan cara melakukan observasi (pengamatan) dengan anak dan orang tuanya yang dijadikan objek penelitian ini. Perilaku anak terhadap lingkungan sekitarnya, belajarnya ibadahnya, keceriaannya, pergaulannya bersama teman dan sikap orang tua kepada anak, juga sikap anak kepada orang 
36 | Tarbawi : Jurnal Pendidikan Islam Vol. 18. No. I. Januari - Juni 202l

tuanya peneliti amati untuk penyusunan laporan penelitian ini. Pengambilan data juga dengan cara melakukan wawancara melalui tatap muka langsung dengan narasumber (anak, dan ibunya) sesuai dengan pertanyaan-pertanyaan yang telah narasumber persiapkan. Peneliti kemudian merangkum jawaban nasrasumber untuk dijadikan bahan dalam penelitian ini.

\section{PEMBAHASAN}

Penelitian yang dilakukan oleh (Fauzi, 2018) menyatakan bahwa Persepsi masyarakat saat ini telah menjadikan pendidikan Madrasah sebaga pilihan utama (pilihan pendidikan orang tua). Pengajaran dari pendidikan Islam sebagai pendekatan untuk menerapkan Pendidikan Islam di sekolah yang efektif untuk siswa yang mampu menghasilkan individu yang seimbang dalam hal fisik, emosi, spiritual, dan kecerdasan. Perbedaan dari penelitian ini yakni hal tersebut dilaksankan untuk sistem pendidikan Islam di sekolah, sedangkan dalam penelitian lebih memfokuskan ke pendidikan Islam dari orang tua yang lulusan pondok pesantren. Penelitian yang dilakukan ini berkaitan dengan penelitian Ahmad Fauzi adalah mengenai pemilihan orang tua untuk memberikan pendidikan Islam dengan memilih sekolah yang tepat dengan mempertimbangkan segala aspek pendidikan yang ada dalam diri anak.

Penelitian lain yang dilakukan oleh (Das, Halik, dan Amaluddin, 2016) menjelaskan bahwa lulusan pondok pesantren di Indonesia dapat berkembang sesuai tuntutan zaman dengan adanya pembelajaran yang telah dilaksanakan seorang alumni pondok pesantren selama menjadi santri. Baik dari segi agama Islam yang merupakan tujuan utama adanya pendidikan pondok pesantren dan system pendidikan pondok pesantren yang telah sesuai dengan tuntutan zaman. Persamaanya adalah berisi mengenai santri yang mampu beradaptasi dan berkontribusi secara tepat perkembangan modern. Selain itu, ia harus mempertahankan karakterisasi sendiri sebagai dasar moral dan spiritual fungsinya dalam membangun masyarakat agama. Hal tersebut juga dapat dilaksanakan di dalam lingkungan keluarga mereka. Perbedaan yang ada dalam penelitian yang dilakukan oleh Wardah Hanafie Das dengan penelitian ini adalah penelitian oleh Wardah Hanafie Das menjelaskan secara rinci mengenai sistem di pondok pesantren di Indonesia yang berkembang sesuai tuntutan zaman sedangkan, dalam penelitian ini adalah berisi tentang penerapaan lulusan pondok pesantren ke[ada anaknya di dalam lingkungan keluarga. 
Penelitian oleh Maimun Aqsa Lubis (Lubis, 2015) menjelaskan bahwa sistem pendidikan yang memberikan keluwesan kepada warga muslim di Brunei yaitu sistem pendidikan terpadu untuk mensejajarkan atau menyeimbangkan warga muslim dan warga non muslim. Perbedaan yang mencolok adalah penelitian oleh Maimun Aqsha Lubis menjelaskan mengenai system pendidikan Islam terpadu yang ada di Brunei untuk pendidikan Islam anak disana. Penelitian itu menjelaskan mengenai pendidikan Islam pada anak muslim di sekolah. Hal yang berkaitan dengan penelitian penulis ini adalah langkah orang tua daalm memilih pendidikan untuk anaknya yang lebih kompleks di sekolah dengan memilih sekolah yang system pendidikannnya terdapaat pendidikan tentang pengajaran agama Islam. Hal tersebut dilakukan agar anak dapat lebih mendalami agamanya sendiri.

\section{Pondok Pesantren dan Pendidikan Islam Orang Tua}

"Manfred Ziemek dikutip oleh Kompri dalam Manajemen dan Kepemimpinan Pondok Pesantren menjelaskan bahwa pondok berasal dari kata funduk (Arab) yang berarti raung tidur atau wisma sederhana, karena pondok memang merupakan tempat penampungan sederhanan bagi para pelajar yang jauh dari tempat asalnya. Adapun kata pesantren berasal dari kata santri yang diimbuhi awalan pe- dan akhiran -an yang berarti menunjukkan tempat, maka artinya adalah tempat para santri. Terkadang juga dianggap sebagai gabungan kata santri (manusia baik) dengan suku kata (suka menolong), sehingga kata pesantren dapat berarti tempat pendidikan manusia baikbaik (Kompri, 2018).“

Pondok pesantren adalah tempat pendidikan Islam tradisional yang berkembang di Indonesia. Di dalam pondok pesantren, para santri mempelajrai banyak hal tentang ilmu-ilmu keagamaan. Diantara ilmu keagamaan tersebut yaitu, Ushul Fiqih, Hadis, Nahwu Shorof, dan lainnya. Para santri dituntut bisa memhami dan melaksanakn ilmu-ilmu keagamaan yang telah dipelajarinya.

Tujuan adanya pondok pesantren menurut H. M. Arifin yang dikutip Mahmud dan dikutip oleh Kompri (Kompri, 2018: 3-4) dibagi dalam 2 hal utama yaitu:

1. Tujuan umum

Tujuan umum didirikannya pondok pesantren adalah membimbing santri menjadi manusia yang memiliki sikap yang mencerminkan seorang muslim, para santri nantinya dapat menjadi mubalig dalam masyarakat melalui ilmu agama yang telah dipelajarinya. 
38 | Tarbawi : Jurnal Pendidikan Islam Vol. 18. No. I. Januari - Juni 202I

2. Tujuan khusus

Tujuan khusus didirikannya pondok pesantren adalah mempersiapkan para santri menjadi orang yang memilki ilmu dan mengamalkan ilmunya dalam keluarga dan masyarakat.

Berdasarkan tujuan didirikannya pondok pesantren yang telah disebutkan, maka para santri dapat mengamalkan ilmu yang dimilkinya dalam kehidupan berkeluarga dan bermasyarakat. Pendidikan Islam, seperti pondok pesantren juga bertujuan agar alumni pondok pesantren (santri) mampu mengimplementasikan daalm kehidupan sehari-hari yang berakitan dengan tugas manusia yaitu sebagai kholifah fi al-ard (pemimpin di bumi) dan sebagai hamba sang Khaliq Yang Esa (Tolchah, 2015). Ketika seorang santri menikah, maka tanggung jawabnya adalah untuk keluarganya, baik tanggung jawab lahir dan batin kepada istri dan anakanaknya. Disebutkan bahwa kewajiban orang tua kepada anaknya adalah memilihkan nama yang terbaik, memberikan akikah, memberikan hak hidup, dan memberikan pendidikan yang layak (Musyafa, 2016). Tanggung jawab kepada anaknya untuk masa depan anaknya sendiri. Pendidikan orang tua memengaruhi pendidikan anak dalam keluarga. Orang tua dari alumni pondok pesantren memilki kecakapan khusus tentang agama yang lebih mendalam. Karena pendidikan pondok pesantren memberikan pengajaran yang lebih banyak mengenai keagamaan (Islam).

Aqidah dan keimanan harus diajarkan orang tua kepada anaknya, agar anak dapat mengikat keyakinananya hanya kepada satu keyakinan, yaitu hanya kepada Allah (Nasution, 2019). Dipandang dari sudut potensi yang dimilki oleh manusia dibagi menjadi dua (2) jenis potensi yaitu potensi lahir atau fisik dan potensi batin atau rohani (Daulay, 2014). Potensi-potensi yang dimilki oleh anak dapat digali dan dikembangkan ke arah kesempurnaan dan mencegah atau mengendalikan perubahan-perubahan ke arah yang tidak baik (Darmadi, 2018). Pendidikan sebagai sarana sosialisasi anak yang memilki fungsi mentransformasikan (merubah) seorang anak dan memengaruhi orang-orang disekitarnya ke tujuan hidup yang lebih baik. Pendidikan dengan keadaan sosial masyarakat di lingkungan anak saling terkait, karena pada dasarnya manusia mengalami sosialsasi sesuai dengan kebutuhan manusia bahwa mereka saling membutuhkan. Berdasarkan hal tersebut, maka pendidikan Islam merupakan upaya mengembangkan seluruh potensi invidual dan sosial manusia berdasarkan ajaran Islam (Suryadi, 2018). 


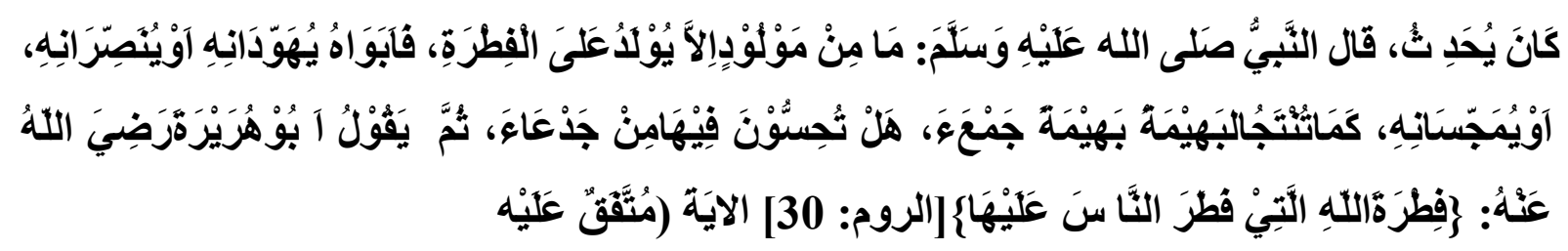

“Terjemahan hadis riwayat Muttafaq'Alaih dikutip oleh Ashif Az Zafi dan Amiruddin di atas berbunyi: Dari Abu Hurairah r.a. berkata, Rasulullah SAW bersabda: Tidak ada seorang anak (adam) melainkan dilahirkan atas fitrah (Islam), maka kedua orang tuanyalah yang menjadikannya beragama yahudi atau beragama majusi. Bagaikan seekor binatang melahirkan seorang anak. Bagaimana pendapatmu apakah didapati kekurangan? Kemudian Abu Hurairah membacakan firman Allah (Q.S. arRum: 30 ). (tetaplah atas) Firman Allah yang telah menciptakan manusia menurut fitrah itu. Tidak ada perubahan pada fitrah Allah (Zafi dan Amiruddin, 2020)."

Berdasarkan terjemahan hadis tersebut, maka dapat dipahami bahwa status setiap anak adalah bersih, suci baik anak seorang muslim maupun anak seorang non muslim, kemudian orang tuanyalah yang memelihara dan memperkuat kelslamannya atau bahkan menjadikan menjadi seorang non muslim, seperti Yahudi, Nasrani, dan Majusi (Zafi dan Amiruddin, 2020). Hadis tersebut di atas memperkuat bahwa pendidikan dari orang tua memberikan pengaruh yang kuat terhadap pendidikan Islam anaknya (Zafi dan Amiruddin, 2020). Jadi adanya hal tersebut tentang keagamaan anak, ketika telah jelas agama Islam yang diharapakan orang tua untuk dianut anaknya maka tugas orang tua adalah memperkuat nilai-nilai atau pelajaran-pelajaran keagamaan tentang pengajaran kelslaman. Berikut ini adalah aspek-aspek yang perlu diperhatiakan dalam pelaksanaan pendidikan Islam pada anak (Daulay, 2014):

1. Aspek pendidikan ketuhanan dan akhlak

Aspek pendidikan ketuhanan berkaitan dengan pendidikan untuk menjalankan perintah Allah dan menjauhi larangan-Nya. Sedangkan pendidikan akhlak berkaitan dengan pendidikan tingkah laku terpuji dan menjauhi tingkah laku tercela.

2. Aspek pendidikan akal dan ilmu pengetahuan

Aspek pendidikan akal dan ilmu pengetahuan berkaitan dengan pendidikan pengetahuan anak.

3. Aspek pendidikan fisik

Aspek ini berkaitan dengan pengembangan dan pemeliharaan jasmani agar tetap sehat. 
40 | Tarbawi : Jurnal Pendidikan Islam Vol. 18. No. I. Januari - Juni 202I

4. Aspek pendidikan kejiwaan

Aspek ini berkaitan dengan pendidikan agar anak tidak mengalami segala jenis penyakit kejiwaan.

5. Aspek pendidikan keindahan (seni)

Aspek ini berkaitan dengan kesenian seperti pujian sholawat.

6. Aspek pendidikan keterampilan

Aspek ini berkaitan dengan pengembangan potensi yang dimilki anak.

7. Aspek sosial

Aspek ini berkaitan dengan pendidikan cara anak untuk bersosialisasi dalam masyarakat, baik dengan antar individu ataupun kelompok.

\section{Implementasi Pendidikan Islam dari Orang Tua Pondok pesantren}

Anak adalah anugerah dari Allah dan sangat dinantikan kehadirannya bagi setiap orang tua (Sinaga, 2018). Adanya anak yang telah lahir di dunia dari kandungan seorang ibu, sangat disyukuri bagi keluarga. Orang tua bertugas untuk mendidik dan menyayangi anaknya. Tidak hanya orang tua yang harus menyanyangi seorang anak, semua orang juga harusnya menyayangi semua anak meskipun anak tersebut bukanlah anak yang dilahirkannya ataupun anak tersebut masih keluarganya. Pembentukan pendidikan Islam yang kuat anak paling utama yang memengaruhinya adalah orang tua. Keluarga merupakan kelompok yang terdiri dari bapak, ibu, dan anak-anak. Bapak sebagai pemimpin keluarga dan ibu yang mengatur rumah tangga, merupakan pemeran yang paling utama dalam proses pendidikan Islam anak-anak, yang meliputi pembinaan, memerhatikan pertumbuhan, dan memerhatikan perkembangan anak. Pendidikan Islam anak sangat bergantung kepada upaya yang dilakukan kedua orang tua yang berisi mengenai pemahaman dalam berbagai pengalaman baik melalui bimbingan, latihan, terutama melalui proses pembinaan keagamaan dengan baik. Melalui semangat keagamaan yang dilaksanakan orang tua kepada anak-anaknya dilaksanakan untuk dapat menjadikan anak-anak memilki akhlak yang Islami atau akhlak terpuji.

Anak sebagai salah satu penentu masa depan suatu bangsa, sangat berperan penting dalam menentukan kemajuan bangsa. Hal itu dikarenakan anak akan menjadi generasi muda yang diharapkan dapat membanggakan dan memajukan bangsanya. Indonesia sendiri menjaga anak-anak bangsa dengan bukti direleasikannya lembaga perlindungan anak. Seperti didirikannya KPAI (komisi perlindungan anak). Anak 
sebagai generasi penerus bangsa, haruslah disayang dan diajari hal-hal yang baik. Saat ini banyak anak yang kurang memiliki perilaku yang baik (akhlak terpuji) terhadap orang sekitarnya yang lebih tua. Akhlak terpuji haruslah diajarkan kepada anak. Tidak hanya itu saja, akan tetapi juga mengajarkan hal yang tidak boleh dilakukan anak.

Keluarga sebagai lingkungan pertama yang sangat dekat dengan anak, diharapkan mampu memberikan pengajaran kepada anak. Sikap anak dapat dipengaruhi juga oleh lingkungan masyarakat tempat tinggal anak. Oleh karena itu, sebaiknya orang tua memperhatikan lingkungan sekitar tempat tinggalnya untuk dapat mencegah atau mengontrol perilaku anak, agar anak memiliki sikap yang baik. Terdapat anak yang berasal dari orang tua pondok pesantren yang berarti orang tua anak pernah menempuh pendidikan pondok pesantren. Pondok pesantren dengan segala peraturannya dapat membuat para santrinya menjadi lebih baik, karena setiap pendidikan memiliki visi da misi yang baik, baik pendidikan formal maupun pendidikan nonformal. Lulusan pondok pesantren salaf biasanya akan mudah berbaur dengan masyarakat dan akan lebih dihargai keadaanya oleh oang disekitar tempata tinggalnya. Orang tua pastinya menginginkan hal-hal yang baik untuk masa depan anak-anaknya. Orang tua pondok pesantren biasanya akan lebih mementingkan pengajaran agama kepada anak-anaknya, karena mereka merasa pendidikan agama sangat penting bagi anak-anaknya untuk bekal di dunia dan akhirat nantinya. Hal tersebut untuk lebih jelasnya dapat dilihat dari adanya penelitian ini, mengenai implementasi pendidikan Islam dari orang tua pondok pesantren.

Seorang anak yang memiliki orang tua alumni dari pondok pesantren, sangat memerhatikan agama. Meskipun kedua orang tuanya bekerja, anak tetap diperhatikan pendidikan Islamnya. Anak yang selalu diarahkan dari kecil untuk melaksanakan solat lima waktu secara berjamaah akan mulai terbiasa dan akan terbiasa hingga mereka dewasa dan menua. Motivasi yang dilakukan oleh orang tua dan diaplikasikan juga oleh orang tua mengenai pengajaran agama Islam dilakukan agar anak melaksanakan hal-hal yang wajib dan baik untuk dilakukan sebagai seorang muslim, sehingga akan terjadi sebuah perubahan kearah yang lebih baik dan bahagia di dunia serta di akhirat. Usaha inilah yang dilakukan oleh orang tua terhadap anak-anaknya di dalam rumah agar anak mereka mencerminkan perilaku sebagai seorang muslim. Pembiasaan menjadi cara yang sangat strategis dalam pendidikan Islam anak untuk lebih memahami dan mengalokasikan Islam dalam kehidupannya. Pembiasaan tersebut dilakukan secara terus menerus agar melekat dalam jiwa anak, dan kebiasaan anak 
akan terbawa sampai ia dewasa, bahkan sampai tua (Hanafi, Adu, dan Zainuddin 2018). Pendidikan Islam tersebut dikatakan sebagai metode pembiasaan dalam pendidikan.

Imam al-Ghazali yang dikutip oleh Abdullah Kafabihi Mahrus menyebutkan bahwa pendidikan Islam pada anak dapat dilaksanakan melalui beberapa metode atau cara, yaitu menggunakan metode cerita (orang tua bercerita tentang kepada anak yang berisi hiburan dan teladan bagi pembentukan tingkah laku yang terpuji anak), metode pemberian hadiah sebagai motivasi, metode bimbingan kesederhanaan pola hidup kepada anak (mengarahkan anak untuk hidup sederhana dan tidak berlebih-lebihan), metode riyadhoh (latihan) yang dilakukan orang tua untuk melatih anaknya (Mahrus, 2017). Misalnya orang tua melatih anaknya untuk dapat melaksankan puasa dari umur anak yang dianggap sudah dapat melaksanakan puasa.

Sejak lahir anak-anak menghabiskan banyak waktunya dengan orang tua Sejak bangun tidur hingga pergi tidur kembali. Umur yang bertambah pun anak-anak masih banyak menghabiskan waktunya dengan orang tua dan keluarga. Orang tua sebagai orang yang telah mengenal dan mengetahui karakter dan sikap anak pastinya tahu cara memerlakukan atau mendidik anaknya agar dapat sesuai dan tercapai seperti yang diinginkan orang tuanya. Kebanyakan orang tua pastinya menginginkan anaknya memiliki karakter dan sikap yang baik. Hal itulah nantinya yang akan dijadikan acuan bagi orang tua muslim untuk mendidik anaknya. Orang tua juga memantau perkembangan anaknya untuk dapat dikendalikan sikap, sifatnya atau lainnya sesuai ajaran agama Islam (aspek-aspeknya).

Lingkungan keluarga meruapakan tempat dimana di dalamnya anak-anak berinteraksi dengan ayah, ibu, kakak, dan adik mereka. Berdasarkan hal itu berdampak bagi anak untuk mudah memperoleh sentuhan pendidikan berupa pembentukan pembiasaan-pembiasaan seperti cara makan, tidur, bangun pagi, berpakaian, sopan santun, beribadah, dan sebagainya. Keluarga akan banyak membantu dalam meletakkan dasar-dasar pembentukan pendidikan Islam pada anak. Orang tua yang memperbolehkan anaknya untuk bermain di luar juga dapat melaksanakan pendidikan Islam melalui hal tersebut. Tetapi masih dalam pengawasan orang tua, sehingga orang tua dapat memberikan pemehaman kepada anak mengenai hal yang baik dan yang tidak baik dilakukan atau dilaksanakan. 
“Imam Ghazali dalam buku Kajian Taklim Muta'allim 2 menjelaskan bahwa orang tua sebaiknya mempersilahkan anaknya untuk bermain dengan temantemannya dengan catatan permainan yang tidak melanggar agama dan berteman dengan teman yang baik agar bisa mengambil pelajaran dari teman tersebut (Mahrus, 2017)."

Melalui kegiatan bermain, anak usia dini dan anak usia sekolah yang masih suka bermain dapat mengembangkan aspek perkembangannya, baik aspek akhlak, kognitif (pengetahuan), fisik-motorik (gerak), bahasa, dan sosial-emosional (perasaan). Bermain menjadikan anak menjadi sehat karena bergerak bebas, terlatih pola pikirnya untuk membuat strategi bermain dan terasah hatinya untuk bersikap jujur, menaati aturan bersama dan mengenal berbagai karakter temannya. Dan tugas orang tua adalah membina anak agar memiliki akhlak terpuji dari pengalaman bermain anak (misalnya, cara sosialisasi yang baik dengan temannya). Tidaklah mudah, oleh karena itu perlu metode pembiasaan. Tidak jauh berbeda dengan anak usia remaja yang tidak lagi pada masa bermain, hendaklah orang tua membiasakan dirinya untuk melakukan yang baik, yang diharapkan nanti anak akan memiliki akhlak terpuji tersebut, menjauhi akhlak tercela dan dapat menerapkan pendidikan agama Islam yang meliputi doa, solat, dan membaca alquran dalam kehidupannya. Metode pembiasaan yang dilakukan orang tua membuat anak cenderung melakukan yang baik dan meninggalkan yang kurang baik. Pendidikan agama Islam meliputi perilaku yang sesuai dengan agama Islam dalam keluarga yang terjadi dilaksanakan melalui semua pengalaman anak, diantaranya adalah baik melalui ucapan yang didengar anak, tindakan, perbuatan dan sikap yang dilihat anak, maupun perlakuan yang dirasakan anak dalam keluarga.

Sikap orang tua yang mengajarkan agama Islam kepada anak-anaknya akan menimbulkan pembelajaran-pembelajaran hidup dalam diri anak yang sesuai dengan agama Islam, perilaku yang akan menjadi bagian dari perilaku anak-anaknya di kemudian hari. Apabila anak dibiasakan melakukan hal-hal yang baik, maka akan tumbuh tenang ketika melakukan ibadah tersebut dan apabila tidak melaksanakannya maka akan terasa kurang dalam hidupnya. Melalui pembiasaan, akan membawa kebaikan di kehidupan anak. Anak yang dibiasakan dengan hal tersebut dengan sendirinya akan tergerak dengan sendirinya untuk melakukannya tanpa disuruh dari orang tua atau orang lainnya. Pembiasaan yang berkaitan dengan syariat Islam yang 
menyangkut perilaku dan ibadah yang berhubungan dengan antar sesama manusia dan hubugan kepada Allah.

Kewajiban dan tanggung jawab orang tua kepada anaknya yaitu kewajiban menafkahi, kewajiban memimpin dan kewajiban mendidik. Sikap dan pandangan orang tua terhadap Islam akan mencerminkan kepada anak. Apabila orang tua menghormati syariat agama Islam, maka dalam diri anak akan tumbuh sikap menghargai dan menghormati syariah agama Islam dan melaksanakannya. Orang tua yang memiliki pendidikan agama Islam yang kuat akan memunculkan pada diri anak menjadi pribadi yang memiliki pengetahuan agama Islam yang luas dan kuat. Arti kata luas disini adalah bahwa anak akan mengerti banyak hal mengenai agama Islam yang telah diceritakan atau diterapkan dalam kehidupan anak di keluarganya. Lingkungan luar juga memengaruhi anak dalam pendidikan agama Islam. Tetapi yang paling utama adalah pendidikan dari orang tua untuk mengontrol sikap dan perilaku anak dari pengaruh luar (tetangga atau masyarakat sekitar). Hal tersebut merupakan tanggung jawab dari para orang tua. Dalam pelaksanaannya banyak orang tua yang berasal dari pondok pesantren mewujudkan keluarga yang berlandaskan agama Islam yang lebih kuat dalam kehidupannya. Merekan mendidik anak mereka dengan pengajaran agama yang telah lebih banyak diketahui orang tua yang berasal dari pondok pesantren.

\section{SIMPULAN}

Peran orang tua paling utama dalam pendidikan Islam anak, karena termasuk sebagai pembina sekaligus pendidik pertama. Kehidupan orang tua sehari-hari yang dilihat oleh anak menentukan perilaku kehidupan memengaruhi diri anak dalam keluarga dan di luar kelurga terkait dengan tingkat pendidikan Islam anak. Oleh karena itu, baik buruknya akhlak anak banyak ditentukan oleh pendidikan Islam yang diajarkan oleh orang tua, orang tua lulusan pondok pesantren lebih memerhatikan pengaruh-pengaruh sosial dan lingkungan anak. Pondok pesantren sebagai wadah pendidikan yang lebih menekankan ke pendidikan keagamaan, dapat membuat lulusan dari pondok pesantren menjadi pribadi yang postif di dalam keluarganya dan kehidupan bermasyarakatnya sesuai dengan ilmu-ilmu keagamaan yang telah banyak dipelajarinya. Implementasi pendidikan Islam dari orang tua pondok pesantren telah dilaksanakan dengan baik. Karena para orang tua alumni pondok pesantren telah terbiasa melaksanakan kegiatan kegamaan, ibadah, dan akhlak yang dapat dijadikan 
acuan yang baik bagi anak. Hal tersebut adalah merupakan tindakan pendidikan Islam dari orang yang baik. Setiap orang tua yang mempunyai pengetahuan yang mendalam mengenai metode atau cara, langkah, dan hal-hal yang memengaruhi pendidikan Islam anak untuk mendidik anak dengan pengajaran-pengajaran agama Islam agar sang anak menjadi generasi yang saleh dan salehah masa depan.

\section{DAFTAR PUSTAKA}

Ayuhan. 2012. Konsep Pendidikan Anak Salih Dalam Perspektif Islam. Yogyakarta: CV Budi utama.

Bukhari, Ihsan Baihaqi Ibnu. 2015. 7 Kiat Orangtua Shalih Menjadikan Anak Disiplin Dan Bahagia. Bandung: PT Mizan Pustaka,.

Darmadi. 2018. Mendidik Adalah Cinta. Surakarta: CV Kekata Group.

Das, St. Wardah Hanafie, Abdul Halik, and Amaluddin. 2016. "Paradigm of Islamic Education in the Future: The Integration of Islamic Boarding School and Favorite School." ISSN 2220-3796 8 (4).

Daulay, Haidar Putra. 2014. Pendidikan Islam Dalam Perspektif Filsafat. Jakarta: Kencana Prenadamedia Group.

Fauzi, Ahmad. 2018. "Analysis Study of Parental Choice of Education in The Millenial Era Introduction Historically, the Madrasa Education System for the First Time Began in the Reign of Nizam Al-Mulk in Baghdad, Namely in $459 \mathrm{AH}$ and Continues to Experience Its Development 1" 12 (51).

Hanafi, Halid, La Adu, and Zainuddin. 2018. Ilmu Pendidikan Islam. Yogyakarta: CV Budi Utama.

Kompri. 2018. Manajemen Dan Kepemimpinan Pondok Pesantren. Jakarta: Prenadamedia Group.

Lubis, Maimun Aqsha. 2015. "Effective Implementation of the Integrated Islamic Education." Global Journal Al-Thaqafah $5 \quad$ (1).. https://doi.org/10.7187/GJAT792015.05.01.

Mahrus, Abdullah Kafabihi. 2017. Kajian Dan Analisis Taklim Muta'allim 2 Dilengkapi Dengan Komponen-Kompen Pendidikan Yang Terdapat Dalam Kitab Ihya' Ulumuddin. Surabaya: Santri Salaf Press.

Muhdi, Ahmad Adip. 2018. Manajemen Pendidikan Terpadu. Malang: CV. Literasi Nusantara Abad. 
46 | Tarbawi : Jurnal Pendidikan Islam Vol. 18. No. I. Januari - Juni 202I

Musyafa, Haidar. 2016. Agar Nikah Berlimpah Berkah. Jakarta: PT Elex Media Kumputindo.

Nasution, Hasnil Aida. 2019. Patologi Sosial Dan Pendidikan Islam Keluarga. Surabaya: Scopindo Media Pustaka.

Remiswal, and Arham Junaidi Firman. 2018. Konsep Fitrah Dalam Pndidikan Islam. yogyakarta: Diandra.

Sinaga, M. Harwansyah Putra. 2018. Bersahabat Dengan Anak. Jakarta: PT Elex Media Kumputindo.

Suryadi, Rudi Ahmad. 2018. Ilmu Pendidikan Islam. Yogyakarta: CV Budi Utama.

Tolchah, Moch. 2015. Dinamika Pendidikan Pasca Orde Baru. Yogyakarta: PT LKiS Pelangi Aksara,.

Zafi, Ashif Az, and Amiruddin. 2020. Membumikan Hadis- Hadis Pendidikan. Kudus. 